\title{
Mountaineer Boys and Girls Club public relations campaign professional project
}

\author{
Lisa K. Brown \\ West Virginia University
}

Follow this and additional works at: https://researchrepository.wvu.edu/etd

\section{Recommended Citation}

Brown, Lisa K., "Mountaineer Boys and Girls Club public relations campaign professional project" (2010). Graduate Theses, Dissertations, and Problem Reports. 3214.

https://researchrepository.wvu.edu/etd/3214

This Thesis is protected by copyright and/or related rights. It has been brought to you by the The Research Repository @ WVU with permission from the rights-holder(s). You are free to use this Thesis in any way that is permitted by the copyright and related rights legislation that applies to your use. For other uses you must obtain permission from the rights-holder(s) directly, unless additional rights are indicated by a Creative Commons license in the record and/ or on the work itself. This Thesis has been accepted for inclusion in WVU Graduate Theses, Dissertations, and Problem Reports collection by an authorized administrator of The Research Repository @ WVU. For more information, please contact researchrepository@mail.wvu.edu. 
Mountaineer Boys and Girls Club Public Relations Campaign

Professional Project

\author{
Lisa K. Brown
}

Professional Project submitted to the Perley Isaac Reed School of Journalism

at West Virginia University

in partial fulfillment of the requirements

for the degree of

\author{
Master of Science \\ in \\ Journalism
}

Dr. Ivan Pinnell, Ph.D., Chair
Dr. Stephen Urbanski, Ph.D.
Dr. Kelley Crowley, Ph.D.
Dr. Chad Pierskalla, Ph.D.

Morgantown, West Virginia

2010

Keywords: Journalism, Public Relations, Nonprofit, Relationship Management Theory, Boys \& Girls Club

Copyright 2010 Lisa K. Brown 


\title{
ABSTRACT \\ Mountaineer Boys and Girls Club Public Relations Campaign \\ Professional Project
}

\author{
Lisa K. Brown
}

The task of sustaining a nonprofit organization in a small town can be challenging. These organizations rely on public relations to communicate with the public and maintain their funding. This professional project provides the Mountaineer Boys and Girls Club ("the Club") in Morgantown, West Virginia, with a public relations campaign. The campaign is designed to assist the Club with increasing donations, extending stewardship and increasing website visits from a relationship management perspective. The project also offers other nonprofit staff members with a guide to use when creating their own public relations plans. 


\section{ACKNOWLEDGEMENTS}

To my committee: Thank you for your continued support of this endeavor. Without your guidance and patience, this project would not have been completed. When I needed extra motivation, you pushed me to keep going and refused to accept anything less than my best. Again, thank you.

To my friends and family: Thank you for believing me when I said I would finish. 


\section{TABLE OF CONTENTS}

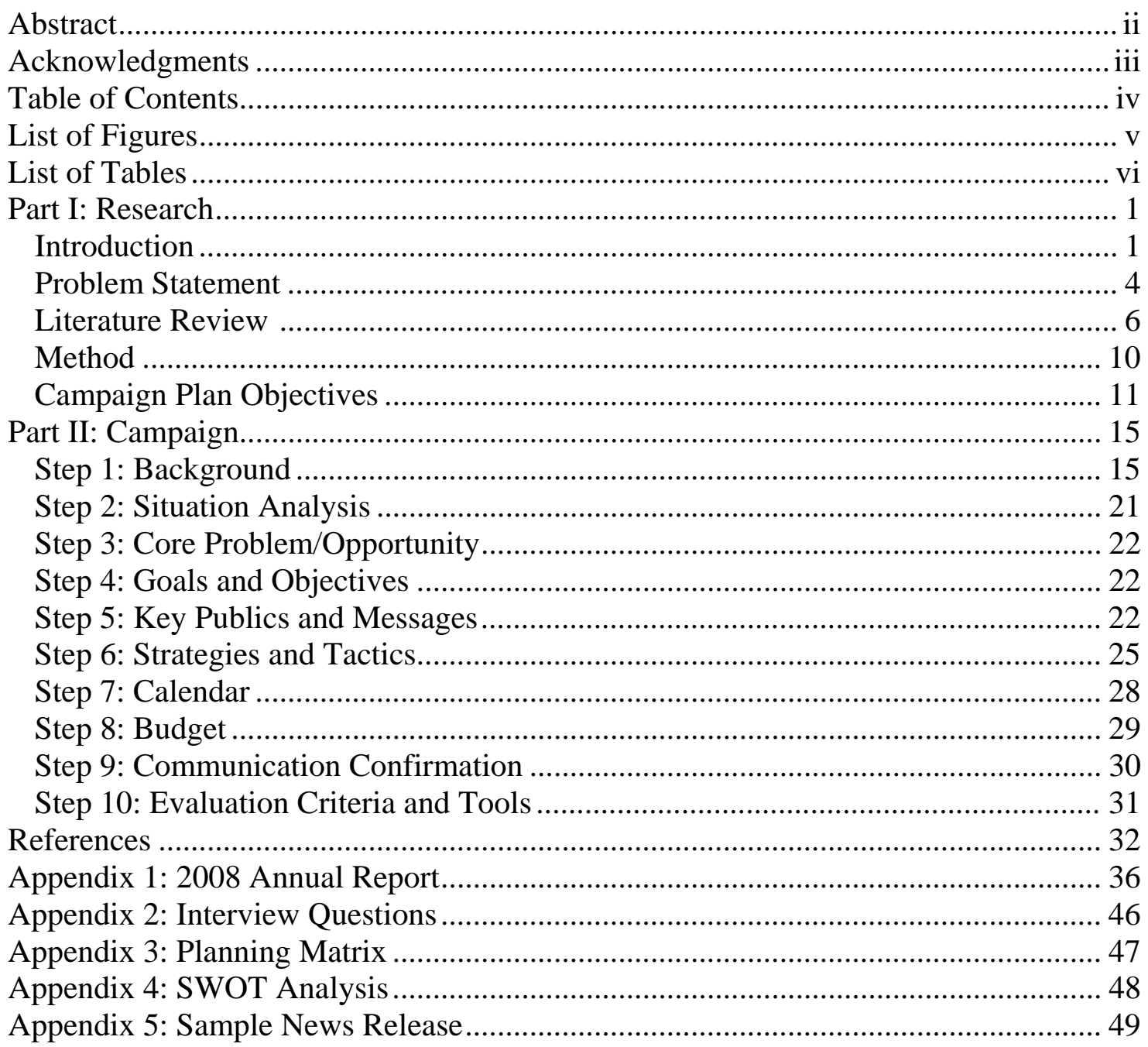




\section{LIST OF FIGURES}

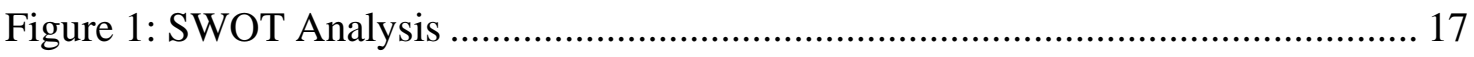

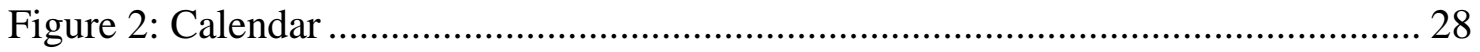

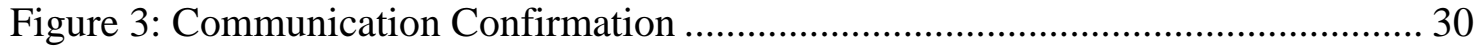




\section{LIST OF TABLES}

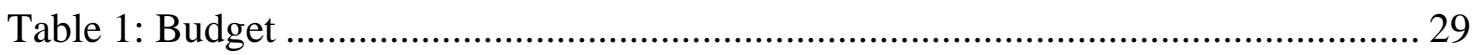




\section{PART I: RESEARCH}

\section{Introduction}

The Mountaineer Boys and Girls Club (“the Club”) plays an important role in lives of families throughout the Morgantown area. Kathy Camp currently sends her two 7-year-olds to the Club and believes it, “...provides a safe and affordable place for children who are too old for daycare who could otherwise be latch-key kids. The Club also encourages family activities in a effort to strengthen the family bond. The summer program is very beneficial and includes lots of activities for children who are outside the daycare age, but still too young to stay home alone. The kids love the field trips and really like going to a pool three days a week.”

Camp insists that her family, as well as the community, would suffer without the Club. She said, "It would be very difficult to find affordable child care for my children. The cost would be much higher, and the provider [I know this from experience] would not spend the time to take the kids to the pool or other activities. I've had other after-school programs that do nothing to help the kids finish homework. The Club helps ensure that children are looked after and that they have fun experiences. There are some who use the Club who wouldn't be able to afford child care if it did not exist. Those children could be left home alone without proper supervision and guidance. I believe the Club is a valuable part of the community because of its affordable and structured fun for the kids.”

Kim Johnson sends her two children, ages 6 and 10, to the Club and she said her family would also endure hardships without it. "Summer daycare, early dismissals and snow day arrangements would be difficult and a financial burden for the family. Most places in Morgantown charge at least $\$ 100$ a week per child in the summer. This is a minimum of $\$ 800$ a month for three months that needs to come out of the budget. Not easy to do.” 
"My children have enjoyed their summers and snow days at the Club. It combines fun while having the children continue their education,“ said Senta Chmiel, another parent. "The staff also eases the stress on the parents by providing transportation from the school to the Club since the parents must work full-time.”

Jackie Paugh said, "I love the Club and my son loves going there. I have a place to send my son for the summer and he is active instead sitting at home and playing video games.” Casandra Hood added, "I am so glad my children can go on trips during the summer. I work full-time and so does my husband so being able to know my children are having fun with people I trust is an extra bonus.”

Without the summer program, Linda Hamrick said that her 12-year-old daughter Micha, "would not receive the supplemental support and guidance she recieves from staff. Also, due to the cost of child care, age-limit restrictions and lack of other programs, Micha would be exclusively a latch-key child during the school year and mostly unsupervised and unstructured during the summer months.”

For Joy Greene, the Club has provided more than just childcare for her family. "My son gets to be around people who are used to dealing with tweens and teens," said Greene. "He values the opinions of people who are younger than his parents, but older than himself. This has been really helpful to him personally.”

As evidenced by interviews with parents who send their children to the Club, the organization provides a vital service to the community. Located in Morgantown, West Virginia, the Club is the local chapter of the Boys and Girls Clubs of America. At the end of 2008, the Club was serving more than 700 members overall and approximately 60 to 70 members per day during the school year. The Club also has a summer program which was serving approximately 
80 to 90 members per day. According to the 2008 Annual Report (Appendix 1), the Club is a “not for profit 501(c) (3) organization dedicated to enhancing the quality of life for youth.” It was created in 1998 as part of the Chamber of Commerce Vision 2000 Plan in an effort to reduce juvenile crime in the area.

The Club's mission statement is stated as the following:

The primary mission of the Mountaineer Boys and Girls Club is to promote health, social education, education enhancement opportunities, and character development for boys and girls grades 1 through 12, by building self-esteem, values, and social skills. The Boys and Girls Club provides programs that are tested, proven, and nationally recognized as successfully addressing the most critical issues affecting today's youth. The Club also provides them with the knowledge, skills, and attributes they need to pursue their dreams and succeed in life (2008 Annual Report).

The Boys and Girls Clubs of America is a nonprofit organization that, according to its website, serves 4.5 million children with 4,300 locations throughout the country, as well as Puerto Rico, the Virgin Islands and U.S. military bases worldwide. The organization's mission is "To enable all young people, especially those who need us most, to reach their full potential as productive, caring, responsible citizens”(bgca.org).

Interviews with Dennis Poluga, the president of the chapter, and Nicole Riggleman, an employee, were conducted. The questions are included as Appendix 2 and the following information is based on their responses.

The members pay a fee that ranges from nothing to $\$ 35$ a month, which is determined by the family's income. The Club currently offers several education, recreation, prevention and community service programs for its members. The education and recreation programs serve approximately 125 members a year, while the prevention classes and community service programs serve approximately 70 to 100 members a year. These programs include: 
- Project Learn

- Power Hour

- Career Launch

- Mentoring

- Smart Moves

- Fitness Hour

- VeggieU

- The Virtues Initiative

- Youth United

- Family PLUS program.

The Club and its programs are led by two full-time staff members, two AmeriCorps VISTA members, six part-time employees, approximately 15 federal work-study student employees, two part-time interns and more than 200 volunteers a year.

According to Poluga, the Club receives funding from several different sources:

- $\$ 86,000$ from private donations

- $\$ 35,000$ from corporations

- $\$ 20,000$ from foundations

- $\$ 31,000$ from individuals

- $\$ 28,909$ from United Way

- $\$ 179,567$ from government funding (local, state and federal)

- $\$ 28,790$ from membership fees

The Club’s income totals to $\$ 323,266$ with approximately 20 percent of it being spent on operational needs such as utilities, rent, gas, equipment and supplies — items that are not directly related to programs and services. Any funding received from National Headquarters is in the form of federal grants or corporate donations.

\section{Problem Statement}

The Mountaineer Boys and Girls Club is currently underfunded in areas that involve facility and transportation costs. According to Poluga, "For the most part, funding agencies are only willing to fund a specific program that will provide services to a Club population, but most 
funding agencies are not willing to pay for rent, telephone, utilities, etc. Transportation and utilities are areas that are the most underfunded.” Poluga believes that the Club would be more successful in its mission if it acquired a more stable stream of local funding to meet these operational needs.

Based on this information, a public relations campaign was designed with the goal of developing a stable stream of local funding for these areas. According to Poluga, these costs amount to roughly $\$ 64,653$ per year. For many nonprofits, the task of raising funds can be challenging, especially at the local level. A key strategy to fundraising is through private donations; however, "if the public does not know what the organization is and what it does, then the public does not donate money” (Dyer, Buell, Harrison, \& Weber, 2002, p. 15). Therefore, organizations can utilize public relations to communicate with the public and ultimately increase its funding.

Another problem that this project will address is the gap in research pertaining to nonprofit public relations campaigns. There is a lack of specific templates for small, local nonprofit organizations to refer to when designing a public relations campaign. Therefore, this campaign also intends to provide these organizations with a template to use when creating their own public relations campaign. According to the Urban Institue’s National Center for Charitable Statistics, there were 37,009 501(c)(3) public charities in 2007 with an expense level between \$250,000 and \$499,999. Given that the Mountaineer Boys and Girls Club falls into that category, it can be assumed that these organizations also have little or no budget for public relations. 


\section{Literature Review}

This literature review will examine public relations research and the models that have been developed by researchers and public relations practicioners. Additionally, this review will assess how public relations benefits nonprofit organizations and which model would be most effective for the Club.

How do nonprofit organizations use public relations? Kate Luckert defines a nonprofit as an organization that "is formed for the purpose of serving a public or mutual benefit other than the pursuit or accumulation of profits for owners or investors (Luckert).

Coombs (2001) defined public relations as "the use of communication to manage the relationships between an organization and its stakeholders” (Coombs, p. 106). Stakeholders are defined by Freeman (1984) as “' any group or individual who can affect or is affected by the achievement of the firm's objectives'” (Freeman, p. 25).

Relationship management theory. The public relations campaign for the Club was developed from a relationship management perspective. According to Ledingham (2003), “The relationship management perspective holds that public relations balances the interests of organizations and publics through the management of organization - public relationships” (Ledingham, p. 181). He writes that this approach allows organizations and its publics to interact in a way that is beneficial to both parties (Ledingham, 2003, p. 190). Ferguson’s conference paper in 1984 often receives credit as the "first attempt to survey theory in public relations" (Botan \& Taylor, 2004, p. 648). He was also the first to suggest focusing on the "relationships between organizations and their publics as the unit of analysis and focus of theorizing” (Botan \& Taylor, 2004, p. 648). 
Cheney and Christensen (2001) write that in theory, public relations is about "two-way relationships” (Cheney \& Christensen, p. 180). They also write that organizations have realized that its friendships are just as important as its customers. Consequently, these organizations "find themselves involved in activities aimed at forging long-term mutual relationships with internal and external audiences” (Cheney \& Christensen, 2001, p. 180). Springston, Keyton, Leichty and Metzger (1992) also support this belief by writing that recognizing an organization’s "management of interdependence with relevant publics" provides a strong theoretical basis when practicing public relations (Springston et al., p. 82). Communication between an organization and its stakeholders "equates with building relationships vital to creating a sense of community," which can help project a positive image to the public (Starck \& Kruckeberg, 2001, p. 56). This two-way communication serves as the core of the relationship management theory.

The relationship management theory is relevant to this project because the Mountaineer Boys and Girls Club is a nonprofit service organization that relies on its relationship with the community and its stakeholders to succeed. The Club's mission is to support the youth in and around Morgantown and fills a gap between government programs and other social services. Without the community's support in return, the Club would be unable to perform its services. Therefore, by building and maintaining positive relationships with the public, the Club is able to operate successfully. The relationship management perspective advocates that both parties act in a way that is mutually beneficial. For these reasons, the relationship management theory is an appropriate foundation when practicing public relations in a nonprofit organization, specifically the Mountaineer Boys and Girls Club.

The two-way symmetrical public relations model. Grunig (2001) supports the relationship management theory with his “excellent two-way public relations” model which 
allows organizations and publics to negotiate their positions with each other to achieve outcomes in the "win-win zone" which would ultimately benefit both the organization and its publics (Grunig, p. 25-26).

Grunig (2001) defines this two-way symmetrical model as when public relations "practitioners use research and dialogue to bring about symbiotic changes in the ideas, attitudes, and behaviors of both their organizations and publics" (Grunig, p. 12). This model is "generally viewed as a positive model of excellence for public relations practice” (David, 2004, p. 185). It is also described as an organization being willing to listen and respond to its stakeholders concerns (Roper, 2005, p. 69). Botan and Taylor (2004) point out that for years, this model “dominated the pages of public relations journals” (Botan \& Taylor, p. 652).

Grunig (2001) credits Murphy with developing the mixed-motive model in which "organizations try to satisfy their own interests while simultaneously trying to help publics satisfy their interests” (Grunig, p. 12). This implies that both the organization and its publics would be satisfied (Roper, 2005, p. 70). Grunig (2001) argues that the mixed-motive model actually describes the two-way symmetrical model as he originally intended (Grunig, p. 12). He suggests that utilizing the two-way symmetrical model or the mixed-motive model "almost always could increase the contribution of public relations to organizational effectiveness” (Grunig, 2001, p. 12).

Critics of the two-way symmetrical model do not believe that it should be "normatively superior" to the other models; some feel that "symmetrical public relations is a utopian ideal that cannot be practiced in reality” (Grunig, 2001, p. 13). Grunig (2001) addressed Van der Meiden’s argument that the symmetrical model requires organizations to "abandon their self-interests", which he considers "unrealistic as well as ill advised" by insisting that the symmetrical model 
"serves the self-interest of the organization better than an assymetrical model” (Grunig, p. 13). He argues that organizations 'get more of what they want when they give up some of what they want' (Grunig, 2001, p. 13).

Organization-public relationship (OPR). Broom, Casey and Ritchey (2000) define organization-public relationships (OPR) as "the patterns of interaction, transaction, exchange, and linkage between an organization and its publics” (Broom, Casey, \& Ritchey, p. 18). Scholars have designed several different methods for measuring OPR, but the most widely used technique is the one created by Hon and Grunig for the Institute of Public Relations (Waters, 2008, p. 76). Waters (2008) used this method to measure the relationships between nonprofits and their donors; he found that repeat donors evaluated the organization more positively than one-time donors (Waters, p. 82). He concluded that organizations should cultivate donors of lower gift levels as well and that "relationship management can produce more satisfied publics" (Waters, 2008, p. 84).

ROPES model. Fundraising is important to any nonprofit entity and its public relations program. Kelly (2001) writes that the fundraising process can represented by the ROPES model, which stands for Research, Objectives, Programming, Evaluation and Stewardship (Kelly, p. 280). An important aspect to fundraising which is sometimes overlooked is the final step: stewardship. Greenfield (1991) states that the purpose of stewardship in regards to fundraising is to thank donors and "establish the means for continued communication that will help to preserve their interest and attention to the organization” (Greenfield, p. 148). Worth (1993) points out that stewardship is actually "an element of cultivation for the next gift, making the [fundraising] process truly a cycle” (Worth, p. 7). Stewardship should be included in any fundraising 
campaign and it is broken down into four parts: reciprocity, responsibility, reporting and relationship nurturing. Kelly (2001) defines the previous components as:

1) Reciprocity-Thanking the donor

2) Responsibility-Showing the donor how the donation was used

3) Reporting-Sending the donor newsletters and annual reports

4) Relationship nurturing-Continuing to ask for support in future fundraising campaigns (Kelly, p. 283-286).

After reviewing the literature, it was determined that the most appropriate public relations model for this campaign is the ROPES model, which operates through a relationship management theory lens. This model appears to be the most suitable for a public relations campaign that intends to increase funding for a nonprofit organization.

\section{Method}

This professional project intends to provide the Mountaineer Boys and Girls Club with a public relations campaign to assist it with raising $\$ 64,653$ of steady local income per year for operational expenses. The Club is not required to implement the campaign; however, that is the intended outcome.

The 10-Step Strategic Communications Planning Matrix (Appendix 3) that was developed at Brigham Young University was used as a guide for the research and planning components of the campaign (Wilson, 2008, p. 12-13). The matrix coincides with the first four steps of the ROPES model and provides a framework for the presentation of the campaign.

Research for the campaign began by evaluating the external environment, industry, services provided, past and present PR strategies and resources available. Staff at the Club have been interviewed and a SWOT analysis was conducted (Appendix 4). The goal and objectives have been set based on information received from Denny Poluga and Nicole Riggleman at the 
Mountaineer Boys and Girls Club. Strategies and tactics have also been determined. These are presented in the next section.

To continue the planning phase, key publics were identified and the appropriate messages for reaching the publics were designed. After the key publics and messages were established, public-specific strategies and tactics to deliver the messages were further developed. Next, the calendar and budget was set and organized by specific tactic. These are displayed in the project as charts. There is also a table that will display each key public and its corresponding interests, messages, influentials, objectives, strategies and tactics. The final step of the Strategic Communications Planning Matrix is "Evaluation”; therefore, an evaluation tool for each objective is included so the success of the campaign — if implemented — can be adequately measured.

\section{Campaign Plan Objectives}

A public relations campaign was developed and presented to the Mountaineer Boys and Girls Club based on interview responses and indications through the lens of the relationship management theory.

The goal of this campaign is to develop a sustainable stream of local funding through the use of public relations for The Mountaineer Boys and Girls Club's operational costs. In order to achieve this goal, the campaign will attempt to accomplish the following objectives:

1) Increase individual donations by 10 percent

2) Extend stewardship to every donor.

3) Increase website visits by 25 percent. 
Objective 1: Increase individual donations by 10 percent.

Why? This campaign will attempt to increase individual donations because as stated earlier, the Club is currently underfunded in operational costs which foundations are generally not willing to fund. Also, despite what some may think, "the largest number of gift dollars has always been contributed [to charitable organizations] by private individuals” (Edles, 1993, p. 4). R. Edwards, Benefield, J. Edwards and Yankey (1997) agree by stating, “Giving to nonprofits by individuals in the United State is more than seven times that of corporations and foundations. Yet, many nonprofits overlook individuals when they develop their fundraising plans” (R. Edwards, Benefield, J. Edwards, \& Yankey, p. 3). In 1999, \$190 billion were donated to charity organizations, with 84 percent being from individuals, 10 percent from foundations and 6 percent from corporations (Kelly, 2000, p. 30).

How? The campaign suggests that the Club seek out new donors and promote awareness of the organization within the community by holding a bike-a-thon. Wendroff (2004) points out that an advantage to holding a community-wide special event is that "the agency has wide exposure to the community, which means excellent public relations opportunities” (Wendroff, p. 42). Many of the Club's current fundraisers do not have the ability to involve the entire community, for example, the Poker Run which attracts only bikers. This type of event would also allow the kids that belong to the Club to participate by volunteering. Additionally, the Club has a positive relationship with West Virginia University, in particularly with the Greek organizations, where a multitude of volunteers and participants could be recruited from. 
Objective 2: Extend stewardship by communicating with every donor.

Why? "The public relations process is incomplete without stewardship...Publics who have demonstrated that they are friends of the organization are deserving of continued attention” (Kelly, 2001, p. 289). Sargeant and Jay (2004) support this notion by discussing the importance of donor rentention. They write that many organizations lose donor support after the first gift, "as many as 50 percent of [donors] recruited never give a second gift. After that, organizations tend to lose 30 percent of the remaining donors each year” (Sargeant \& Jay, 2004, p. 2). They also point out that it "costs up to ten times more to reach a new donor than to successfully communicate with an existing one” (Sargeant \& Jay, 2004, p. 1). Based on interview responses, the Club currently receives roughly 50 percent of its individual donations from repeat donors and only sends newsletters and yearly donation requests to its larger donors. There is an opportunity to communicate with all of its donors to retain a higher percentage.

How ? This campaign suggests that the Club first develop a central donor database that includes donors of all levels and their contact information, including e-mail addresses. Mullen (2006) suggests that a contributor database should also include "contribution history, actual amounts and giving dates, special funding interests, prior recognition, and personal preferences” (Mullen, p. 24). Using this database, the Club can keep track of new and repeat donations and send them a thank-you note, either by e-mail or mail - depending on the gift level. Due to the low budget, the quarterly newsletter should be distributed by e-mail to those who wish to receive it that way. This database will also allow the Club to solicit donations from donors for various fundraisers who do not contribute regularly. 


\section{Objective 3: Increase unique website visits by 25 percent}

Why? Kang and Norton (2004) state that using the Internet as a communication tool will allow nonprofit organizations "to potentially boost their volunteer, donor, and fundraising opportunities” (Kang \& Norton, p. 283). Ingenhoff and Koelling (2009) write that organizations have the ability to use the Internet to engage their publics which is the primary component to Grunig’s excellent public relations theory (Ingenhoff \& Koelling, p. 1). Despite nonprofit organizations having limited resources, they "can still reach a large public by means of a welldesigned Web site” (Ingenhoff \& Koelling, 2009, p. 1).

By nonprofits utilizing their websites effectively, they also have an opportunity to secure donations online. On a national scale, the American Red Cross raised more than \$67 million online and its online supporters grew from 30,000 to 700,000 in the four months after September $11^{\text {th }}$, 2001 (Golden, 2002, para. 2). Kayhko (2009) agrees that “e-philanthropy gives small organizations the ability to use technology and the Internet to cultivate donor relationships” (Kayhko, p. 10). She defines e-philanthropy as “using the Internet for philanthropic purposes” (Kayhko, 2009, p. 10). She adds that an organization's website allows its visitors to develop "familiarity and trust” with the organization (Kayhko, 2009, p. 10).

How ? The campaign recommends that the Club increase the effectiveness of its website by adding elements to its website: www.mbgclub.org. These include a Newsletter page, a Contributors/Supporters page and a Photo Blog page. These items can be easily added and maintained by an intern or volunteer. A copy of the annual report should also be included on the site. These items would benefit parents, as well as donors. E-mail marketing can also be provided by a third-party service to ensure its effectiveness for a small fee (Kayhko, 2009, p. 1011). 


\section{PART II: CAMPAIGN}

As previously stated, the purpse of this professional project is to provide the Mountaineer Boys and Girls Club with a public relations campaign. This campaign is designed to assist the chapter with increasing its local funding. The campaign will also serve as a guide for other similar nonprofit organizations to use in their own public relations efforts.

\section{Step 1: Background}

Located in Morgantown, West Virginia, the Club is the local chapter of the Boys and Girls Clubs of America. At the end of 2008, the Club was serving more than 700 members overall and approximately 60 to 70 members per day during the school year. The Club also has a summer program which was serving approximately 80 to 90 members per day. According to the 2008 Annual Report (Appendix 1), the Club is a "not for profit 501(c) (3) organization dedicated to enhancing the quality of life for youth.” It was created in 1998 as part of the Chamber of Commerce Vision 2000 Plan in an effort to reduce juvenile crime in the area.

The Club’s mission statement is stated as the following:

The primary mission of the Mountaineer Boys and Girls Club is to promote health, social education, education enhancement opportunities, and character development for boys and girls grades 1 through 12, by building self-esteem, values, and social skills. The Boys and Girls Club provides programs that are tested, proven, and nationally recognized as successfully addressing the most critical issues affecting today's youth. The Club also provides them with the knowledge, skills, and attributes they need to pursue their dreams and succeed in life (2008 Annual Report).

The Boys and Girls Clubs of America is a nonprofit organization that, according to its website, serves 4.5 million children with 4,300 locations throughout the country, as well as Puerto Rico, the Virgin Islands and U.S. military bases worldwide. The organization's mission 
is "To enable all young people, especially those who need us most, to reach their full potential as productive, caring, responsible citizens” (bgca.org).

The members pay a fee that ranges from nothing to $\$ 50$ a month per child, which is determined by the family's income. The Club currently offers several education, recreation, prevention and community service programs for its members. The education and recreation programs serve approximately 125 members a year, while the prevention classes and community service programs serve approximately 70 to 100 members a year. These programs include:

- Project Learn

- Power Hour

- Career Launch

- Mentoring

- Smart Moves

- Fitness Hour

- VeggieU

- The Virtues Initiative

- Youth United

- Family PLUS program.

The Club and its programs are led by two full-time staff members, two AmeriCorps VISTA members, six part-time employees, approximately 15 federal work-study student employees, two part-time interns and more than 200 volunteers a year.

According to Poluga, the Club receives funding from several different sources:

- $\$ 86,000$ from private donations:

- $\$ 35,000$ from corporations

- $\$ 20,000$ from foundations

- $\$ 31,000$ from individuals

- $\$ 28,909$ from United Way

- $\$ 179,567$ from government funding (local, state and federal)

- $\$ 28,790$ from membership fees

The Club’s income totals to $\$ 323,266$ with approximately 20 percent of it being spent on operational needs such as utilities, rent, gas, equipment and supplies — items that are not 
directly related to programs and services. Any funding received from National Headquarters is in the form of federal grants or corporate donations.

Figure 1: SWOT Analysis

\begin{tabular}{|c|c|}
\hline $\begin{array}{l}\text { Strengths } \\
\text { Academic support services } \\
\text { Character education programs } \\
\text { Prevention programs } \\
\text { Community service opportunities }\end{array}$ & $\begin{array}{l}\text { Weaknesses } \\
\text { Lack of space } \\
\text { Forced to turn kids away } \\
\text { Lack of funding for utilities, rent, } \\
\text { maintenance and transportation }\end{array}$ \\
\hline $\begin{array}{l}\text { Opportunities } \\
\text { Message of success into the community } \\
\text { More kids in community wish to be } \\
\text { members } \\
\text { WVU and Greek organizations }\end{array}$ & $\begin{array}{l}\text { Threats } \\
\text { Funding agencies only willing to fund } \\
\text { specific programs }\end{array}$ \\
\hline
\end{tabular}

\section{Profiles of Potential Publics}

College Students. Morgantown, West Virginia, is home to West Virginia University which had an enrollment of 28,898 in the fall of 2009 with over 300 student organizations, including Greeks. At that time, the student body was made up of 21,720 undergraduate, 5,349 graduate and 1,829 professional students. There were 15,669 West Virginia residents and 13,229 nonresidents. Within the university is the Center for Civic Engagement, which organizes volunteer opportunities for WVU students and faculty. In 2009, approximately 12,700 WVU students contributed 182,000 hours of service to the community. There are also several courses and programs that require students to volunteer at nonprofit organizations.

Current Relationship: The Club already recruits volunteers, interns and work- 
study employees from WVU. It has also organized fundraisers with Greek organizations and PRSSA.

Influentials: Professors, advisors, peers, media

Self-interests: Resume-building, school/organization requirements, compassion

Past/Current Donors. Private donations for the Club currently comes from corporations, foundations and individuals. These donations total \$86,000 annually. Corporations and foundations generally have set budgets that do not fluctuate very much from year to year. Therefore, there is more opportunity for increased donations from individual donors, which currently accounts for $\$ 31,000$ annually. The Club currently receives roughly 50 percent of its individual donations from repeat donors.

Current Relationship: The Club has a positive relationship with its donors, but it could be improved. Newsletters and yearly donation requests are only sent to its larger donors. There is an opportunity to communicate with all of its donors to retain a higher percentage.

Influentials: Peers, family, media, employers.

Self-interests: Concern for community, philanthropic mentality

Small Businesses. For the purposes of this campaign, a small business is defined as having less than 50 employees. As of 2007, there were a total of 2,149 business establishments in Monongalia County and 2,025, or 94 percent, were small businesses. The majority of these businesses are part of the construction and retail industries.

Current Relationship: The Club regularly seeks donations from various retail outlets for fundraisers. However, there is opportunity to reach out to a wider variety of businesses in a more organized fashion.

Influentials: Customers, employees, peers, media. 
Self-interests: Reputation/image in community, tax incentives, professional success, concern for community.

Local Professionals. This group is comprised of doctors, dentists, pharmacists, attorneys and accountants. Many of them are in private practice and belong to professional associations. The Bureau of Labor Statistics states that in Morgantown, 210 physicians make an average of $\$ 143,970$ annually and dentists make an average of $\$ 129,520$ annually. As of May 2009, there were 150 pharmacists making an average of $\$ 99,520$ annually, 400 accountants and auditors making an average of $\$ 60,160$ annually and 190 lawyers in making an average of $\$ 86,870$ annually.

Current Relationship: The Club has a positive relationship with professionals, but there is an opportunity for more involvement.

Influentials: Peers, employees, media, family, community leaders, clients/patients Self-interests: Personal/professional success, reputation, concern for community. Parents of school-age children. Considering the Club provides services to school-age children, maintaining a relationship with the parents of these kids is vital to its success. According to the latest data, there are 3,148 high school students and 6,798 elementary and middle school students.

Current Relationship: The Club has a positive relationship with the parents of its members.

Influentials: Teachers, other parents, media

Self-interests: Well-being of their children, concern for other children 
Teachers/Educators. There are approximately 3,740 education occupations held in Morgantown. This group is an important resource within the community. Not only are teachers responsible for shaping the lives of the youth, they heavily influence kids and their parents.

Current Relationship: The Club has a positive relationship with teachers and educators in the area.

Influentials: Other teachers/educators, media, community leaders Self-interests: Well-being of children, concern for community

Community Leaders/Politicians. Leaders and politicians within the community have a clear stake in an organization that provides services to the youth. This group is able to show their support for the Club through financial means, as well as publicity and endorsements.

Current Relationship: Some members of this group already support the Club, but there is an opportunity for more support.

Influentials: Peers, constituents

Self-interests: Personal/political success, compassion for community.

Local Media. The local media in Morgantown has the ability to tremendously affect the amount of exposure the Club receives. Within the area, there are two AM radio stations, four FM radio stations, two television stations and two newspapers.

Current Relationship: The Club has a positive relationship with the local media. Influentials: Community leaders, readers, peers Self-interests: Welfare of community, job satisfaction, effective journalism Other organizations/partnership boards. There are several other organizations in the area with a stake in the Club's mission. These include United Way, BOPARC, the Morgantown Bicycle Board and the Youth Commission. These groups tend to have a board of directors with 
members who care about the community and carry a significant amount of influence among decision-makers.

Current Relationship: The club has an active relationship with United Way, which provides grants for specific programs. There is opportunity to develop relationships with other organizations such as BOPARC and the Bicycle Board.

Influentials: Peers, media, employees

Self-interests: Concern for community, personal/professional success

\section{Step 2: Situation Analysis}

The Mountaineer Boys and Girls Club is currently underfunded in areas that involve facility and transportation costs. According to Poluga, "For the most part, funding agencies are only willing to fund a specific program that will provide services to a Club population, but most funding agencies are not willing to pay for rent, telephone, utilities, etc. Transportation and utilities are areas that are the most underfunded.” Poluga believes that the Club would be more successful in its mission if it acquired a more stable stream of local funding to meet these operational needs.

Based on this information, a public relations campaign was designed with the goal of developing a stable stream of local funding for these areas. According to Poluga, these costs amount to roughly $\$ 64,653$ per year. For many nonprofits, the task of raising funds can be challenging, especially at the local level. A key strategy to fundraising is through private donations; however, "if the public does not know what the organization is and what it does, then the public does not donate money” (Dyer, Buell, Harrison, \& Weber, 2002, p. 15). Therefore, organizations can utilize public relations to communicate with the public and ultimately increase its funding. 


\section{Step 3: Core Problem/Opportunity}

The Mountaineer Boys and Girls Club is currently underfunded in areas that involve facility and transportation costs because funding agencies are only willing to fund specific problems.

\section{Step 4: Goals and Objectives}

The goal of this campaign is to develop a sustainable stream of local funding through the use of public relations for The Mountaineer Boys and Girls Club’s operational costs.

Objectives:

1) Increase individual donations by 10 percent

2) Extend stewardship to every donor.

3) Increase website visits by 25 percent.

\section{Step 5: Key Publics and Messages}

Four publics have been chosen for this campaign. I have selected these publics because they appear to have the most potential for increasing individual donations.

\section{Small Businesses}

Primary Message: Participate in the bike-a-thon to show your support for the local community and its youth.

Secondary Messages:

- To raise awareness and financial support for the Club, a bike-a-thon will be held Saturday, April 9, 2011, beginning at Hazel Ruby-McQuain Riverfront Park.

- We encourage you and your employees to participate. We will provide an information packet with details on organizing an office team.

- Involving your business in the bike-a-thon will give you a unique opportunity to promote your business while simultaneously supporting the community.

- Key sponsors will be recognized at the event. 
Primary Message: We want to express our appreciation for your support and encourage

communication to achieve a mutually beneficial relationship.

Secondary Messages:

- Your financial support is important, but we would also appreciate you donating your time to our mission.

- We value your opinions and encourage you to express them.

- We want you to understand the difference that your support makes in lives of the youth in the community.

\section{Local Professionals}

Primary Message: Participate in the bike-a-thon to show your support for the local community and its youth.

Secondary Messages:

- To raise awareness and financial support for the Club, a bike-a-thon will be held Saturday, April 9, 2011, beginning at Hazel Ruby-McQuain Riverfront Park.

- We encourage you, your employees and your colleagues to participate. We will provide an information packet with details on organizing an office team.

- Involving your practice in the bike-a-thon will give you a unique opportunity to promote your services while simultaneously supporting the community.

- Key sponsors will be recognized at the event.

Primary Message: We want to express our appreciation for your support and encourage

communication to achieve a mutually beneficial relationship.

Secondary Messages:

- Your financial support is important, but we would also appreciate you donating your time and/or services to our mission.

- We value your opinions and encourage you to express them.

- We want you to understand the difference that your support makes in lives of the youth in the community.

\section{Past/Current Donors}

Primary Message: We need your continued support through participation in our new bike-a-thon fundraiser. 


\section{Secondary Messages:}

- To raise awareness and financial support for the Club, a bike-a-thon will be held Saturday, April 9, 2011, beginning at Hazel Ruby-McQuain Riverfront Park

- We encourage you, your family and your friends to participate. We will provide an information packet with details on organizing a team.

- Involving your family in the bike-a-thon will give you a unique opportunity to encourage healthy activity while simultaneously supporting the Club.

- Key sponsors will be recognized at the event.

Primary Message: We want to express our appreciation for your support and encourage

communication to achieve a mutually beneficial relationship.

Secondary Messages:

- Your financial support is important, but we would also appreciate you donating your time to our mission.

- We value your opinions and encourage you to express them.

- We want you to understand the difference that your support makes in lives of the youth in the community.

\section{College Students}

Primary Message: We need your support through participation in our new bike-a-thon fundraiser.

Secondary Messages:

- To raise awareness and financial support for the Club, a bike-a-thon will be held Saturday, April 9, 2011, beginning at Hazel Ruby-McQuain Riverfront Park

- We encourage you, your friends and your classmates to participate. We will provide an information packet with details on organizing a team.

- Involving your organization in the bike-a-thon will give you a unique opportunity to encourage healthy activity while simultaneously supporting the Club.

- Key sponsors will be recognized at the event. 


\section{Step 6: Strategies and Tactics}

\section{Small Businesses}

Strategy: Secure the participation and support of small business owners in the bike-a-thon through personal contact.

\section{Tactics:}

- Develop database of small businesses to ensure each one is invited.

- Written invitations with link to registration packets will be hand-delivered to each business by interns.

- Mini-flyers will be left at each business to encourage participation from customers.

- $\quad$ Provide t-shirts for first 20 participants to sign up and prizes/raffle items.

Strategy: Reinforce participation through mass media.

Tactics:

- $\quad$ Send news releases to newspapers and TV stations

- Submit PSAs to local radio stations

- $\quad$ Place ads in newspapers

Strategy: Create strong relationship between business owners and the Club through regular communication.

\section{Tactics:}

- Develop database of contact information, contributions and personal preferences.

- Send thank-you notes, newsletters and invitations on a regular basis.

- Add the following pages to the website: Newsletters, Supporters (with annual report) and a Photo blog.

\section{Local Professionals}

Strategy: Secure the participation and support of local professionals in the bike-a-thon through personal invitations.

\section{Tactics:}

- Develop database of professionals to ensure each one is invited.

- Written invitations with link to registration packets will be delivered by mail to each professional. 
- Mini-flyers will be included in each invitation to encourage participation from clients.

- $\quad$ Provide t-shirts for first 20 participants to sign up and prizes/raffle items.

Strategy: Create strong relationship between professionals and the Club through regular communication.

\section{Tactics:}

- Develop database of contact information, contributions and personal preferences.

- Send thank-you notes, newsletters and invitations on a regular basis.

- Add the following pages to the website: Newsletters, Supporters (with annual report) and a Photo blog.

Strategy: Reinforce participation through mass media.

\section{Tactics:}

- $\quad$ Send news releases to newspapers and TV stations

- Submit PSAs to local radio stations

- Place ads in newspapers

\section{Past/Current Donors}

Strategy: Secure the participation and support of donors in the bike-a-thon through personal invitations.

\section{Tactics:}

- Develop database of donors to ensure each one is invited to participate and/or support the cause.

- Invitations and link to registration packets will be delivered to each donor by mail or e-mail, depending on preferences.

- Provide t-shirts for first 20 participants to sign up and prizes/raffle items.

Strategy: Strengthen relationship between donors and the Club through increased communication.

Tactics:

- Develop database of contact information, contributions and personal preferences.

- Send thank-you notes, newsletters and invitations on a regular basis. 
- Add the following pages to the website: Newsletters, Supporters (with annual report) and a Photo blog.

Strategy: Reinforce participation through mass media.

Tactics:

- Send news releases to newspapers and TV stations

- Submit PSAs to local radio stations

- Place ads in newspapers

\section{College Students}

Strategy: Secure the participation and support of college students and student organizations in the bike-a-thon through personal invitation.

\section{Tactics:}

- Written invitations with link to registration packets will be hand-delivered to each organization by interns.

- Flyers will be posted around campus to encourage participation.

- Provide t-shirts for first 20 participants to sign up and prizes/raffle items.

Strategy: Reinforce participation through mass and social media.

Tactics:

- Send news release to the DA

- Submit PSAs to local radio stations

- Place ads in the DA

- Create event on facebook 
Step 7: Calendar

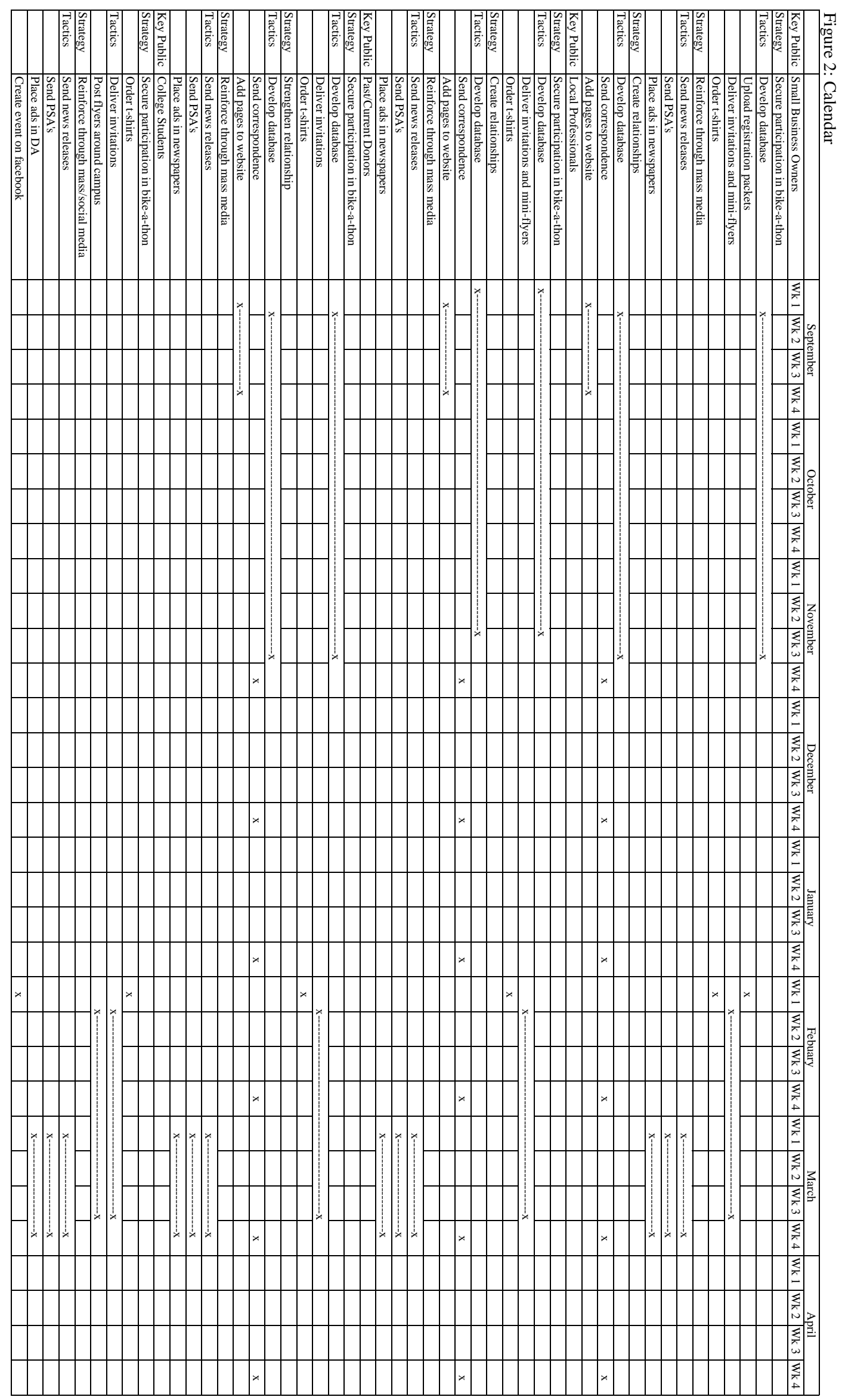




\section{Step 8: Budget}

Table 1: Budget

\begin{tabular}{|c|c|c|c|c|c|c|}
\hline & & Detail & Per Item Cost & Total Projected & Sponsored Credit & Actual Projected \\
\hline Key Public & Small Business Owners & & & & & \\
\hline Strategy & Secure participation in bike-a-thon & & & & & \\
\hline \multirow[t]{8}{*}{ Tactics } & Develop database & Performed by interns & $\$ 0.00$ & $\$ 0.00$ & $\$ 0.00$ & $\$ 0.00$ \\
\hline & Upload registration packets & Performed by interns & $\$ 0.00$ & $\$ 0.00$ & $\$ 0.00$ & $\$ 0.00$ \\
\hline & Deliver invitations and mini-flyers & & & & & \\
\hline & Invitations & $100 @ .04 /$ each & $\$ 0.04$ & $\$ 4.00$ & $\$ 0.00$ & $\$ 4.00$ \\
\hline & Mini-flyers & 100 @.04/each & $\$ 0.04$ & $\$ 4.00$ & $\$ 0.00$ & $\$ 4.00$ \\
\hline & T-shirts for participants & 5 @ 5.95 & $\$ 5.95$ & $\$ 29.75$ & $\$ 0.00$ & $\$ 29.75$ \\
\hline & Prizes/raffle items & Donated & $\$ 0.00$ & $\$ 0.00$ & $\$ 0.00$ & $\$ 0.00$ \\
\hline & & Strategy Subtotal & $\$ 6.03$ & $\$ 37.75$ & $\$ 0.00$ & $\$ 37.75$ \\
\hline Strategy & Reinforce through mass media & & & & & \\
\hline \multirow{4}{*}{ Tactics } & Send news releases & Performed by interns & $\$ 0.00$ & $\$ 0.00$ & $\$ 0.00$ & $\$ 0.00$ \\
\hline & Send PSA's & Performed by interns & $\$ 0.00$ & $\$ 0.00$ & $\$ 0.00$ & $\$ 0.00$ \\
\hline & Place ads in newspapers & Performed by interns & $\$ 0.00$ & $\$ 0.00$ & $\$ 0.00$ & $\$ 0.00$ \\
\hline & & Strategy Subtotal & $\$ 0.00$ & $\$ 0.00$ & $\$ 0.00$ & $\$ 0.00$ \\
\hline Strategy & Create relationships & & & & & \\
\hline \multirow{7}{*}{ Tactics } & Develop database & Performed by interns & $\$ 0.00$ & $\$ 0.00$ & $\$ 0.00$ & $\$ 0.00$ \\
\hline & Send correspondence & & & & & \\
\hline & Letters & $100 @ .04 /$ each & $\$ 0.04$ & $\$ 4.00$ & $\$ 0.00$ & $\$ 4.00$ \\
\hline & Postage & $100 @ .44 /$ each & $\$ 0.44$ & $\$ 44.00$ & $\$ 0.00$ & $\$ 44.00$ \\
\hline & Add pages to website & Performed by interns & $\$ 0.00$ & $\$ 0.00$ & $\$ 0.00$ & $\$ 0.00$ \\
\hline & & Strategy Subtotal & $\$ 0.48$ & $\$ 48.00$ & $\$ 0.00$ & $\$ 48.00$ \\
\hline & & Public Subtotal & $\$ 6.51$ & $\$ 85.75$ & $\$ 0.00$ & $\$ 85.75$ \\
\hline Key Public & Local Professionals & & & & & \\
\hline Strategy & Secure participation in bike-a-thon & & & & & \\
\hline \multirow[t]{7}{*}{ Tactics } & Develop database & Performed by interns & $\$ 0.00$ & $\$ 0.00$ & $\$ 0.00$ & $\$ 0.00$ \\
\hline & Deliver invitations and mini-flyers & & & & & \\
\hline & Invitations & $400 @ .04 /$ each & $\$ 0.04$ & $\$ 16.00$ & $\$ 0.00$ & $\$ 16.00$ \\
\hline & Mini-flyers & 200 @.04/each & $\$ 0.04$ & $\$ 8.00$ & $\$ 0.00$ & $\$ 8.00$ \\
\hline & T-shirts for participants & 5 @ 5.95 & $\$ 5.95$ & $\$ 29.75$ & $\$ 0.00$ & $\$ 29.75$ \\
\hline & Prizes/raffle items & Donated & $\$ 0.00$ & $\$ 0.00$ & $\$ 0.00$ & $\$ 0.00$ \\
\hline & & Strategy Subtotal & $\$ 6.03$ & $\$ 53.75$ & $\$ 0.00$ & $\$ 53.75$ \\
\hline Strategy & Create relationships & & & & & \\
\hline \multirow[t]{5}{*}{ Tactics } & Develop database & Performed by interns & $\$ 0.00$ & $\$ 0.00$ & $\$ 0.00$ & $\$ 0.00$ \\
\hline & Send correspondence & & & & & \\
\hline & Letters & 400 @.04/each & $\$ 0.04$ & $\$ 16.00$ & $\$ 0.00$ & $\$ 16.00$ \\
\hline & Postage & $400 @$ @.44/each & $\$ 0.44$ & $\$ 176.00$ & $\$ 0.00$ & $\$ 176.00$ \\
\hline & & Strategy Subtotal & $\$ 0.48$ & $\$ 192.00$ & $\$ 0.00$ & $\$ 192.00$ \\
\hline Strategy & Reinforce through mass media & & & & & \\
\hline Tactics & Send news releases & Performed by interns & $\$ 0.00$ & $\$ 0.00$ & $\$ 0.00$ & $\$ 0.00$ \\
\hline & Send PSA's & Performed by interns & $\$ 0.00$ & $\$ 0.00$ & $\$ 0.00$ & $\$ 0.00$ \\
\hline & Place ads in newspapers & Performed by interns & $\$ 0.00$ & $\$ 0.00$ & $\$ 0.00$ & $\$ 0.00$ \\
\hline & & Strategy Subtotal & $\$ 0.00$ & $\$ 0.00$ & $\$ 0.00$ & $\$ 0.00$ \\
\hline & & Public Subtotal & $\$ 6.51$ & $\$ 245.75$ & $\$ 0.00$ & $\$ 245.75$ \\
\hline Key Public & Past/Current Donors & & & & & \\
\hline Strategy & Secure participation in bike-a-thon & & & & & \\
\hline Tactics & Develop database & Performed by interns & $\$ 0.00$ & $\$ 0.00$ & $\$ 0.00$ & $\$ 0.00$ \\
\hline & Deliver invitations & & & & & \\
\hline & Invitations & 100 @.04/each & $\$ 0.04$ & $\$ 4.00$ & $\$ 0.00$ & $\$ 4.00$ \\
\hline & Postage & 100 @.44/each & $\$ 0.44$ & $\$ 44.00$ & $\$ 0.00$ & $\$ 44.00$ \\
\hline & T-shirts for participants & 5 @ 5.95 & $\$ 5.95$ & $\$ 29.75$ & $\$ 0.00$ & $\$ 29.75$ \\
\hline & Prizes/raffle items & Donated & $\$ 0.00$ & $\$ 0.00$ & $\$ 0.00$ & $\$ 0.00$ \\
\hline & & Strategy Subtotal & $\$ 6.43$ & $\$ 77.75$ & $\$ 0.00$ & $\$ 77.75$ \\
\hline Strategy & Strengthen relationship & & & & & \\
\hline Tactics & Develop database & Performed by interns & $\$ 0.00$ & $\$ 0.00$ & $\$ 0.00$ & $\$ 0.00$ \\
\hline & Send correspondence & & & & & \\
\hline & Letters & $100 @ .04 /$ each & $\$ 0.04$ & $\$ 4.00$ & $\$ 0.00$ & $\$ 4.00$ \\
\hline & Postage & $100 @ .44 /$ each & $\$ 0.44$ & $\$ 44.00$ & $\$ 0.00$ & $\$ 44.00$ \\
\hline & Add pages to website & Performed by interns & $\$ 0.00$ & $\$ 0.00$ & $\$ 0.00$ & $\$ 0.00$ \\
\hline & & Strategy Subtotal & $\$ 0.48$ & $\$ 48.00$ & $\$ 0.00$ & $\$ 48.00$ \\
\hline Strategy & Reinforce through mass media & & & & & \\
\hline Tactics & Send news releases & Performed by interns & $\$ 0.00$ & $\$ 0.00$ & $\$ 0.00$ & $\$ 0.00$ \\
\hline & Send PSA's & Performed by interns & $\$ 0.00$ & $\$ 0.00$ & $\$ 0.00$ & $\$ 0.00$ \\
\hline & Place ads in newspapers & Performed by interns & $\$ 0.00$ & $\$ 0.00$ & $\$ 0.00$ & $\$ 0.00$ \\
\hline & & Strategy Subtotal & $\$ 0.00$ & $\$ 0.00$ & $\$ 0.00$ & $\$ 0.00$ \\
\hline & & Public Subtotal & $\$ 6.91$ & $\$ 125.75$ & $\$ 0.00$ & $\$ 125.75$ \\
\hline Key Public & College Students & & & & & \\
\hline Strategy & Secure participation in bike-a-thon & & & & & \\
\hline Tactics & Deliver invitations & Performed by interns & $\$ 0.00$ & $\$ 0.00$ & $\$ 0.00$ & $\$ 0.00$ \\
\hline & Post flyers around campus & Performed by interns & $\$ 0.00$ & $\$ 0.00$ & $\$ 0.00$ & $\$ 0.00$ \\
\hline & T-shirts for participants & 5 @ 5.95 & $\$ 5.95$ & $\$ 29.75$ & $\$ 0.00$ & $\$ 29.75$ \\
\hline & Prizes/raffle items & Donated & $\$ 0.00$ & $\$ 0.00$ & $\$ 0.00$ & $\$ 0.00$ \\
\hline & & Strategy Subtotal & $\$ 5.95$ & $\$ 29.75$ & $\$ 0.00$ & $\$ 29.75$ \\
\hline Strategy & Reinforce through mass/social media & & & & & \\
\hline Tactics & Send news releases & Performed by interns & $\$ 0.00$ & $\$ 0.00$ & $\$ 0.00$ & $\$ 0.00$ \\
\hline & Send PSA's & Performed by interns & $\$ 0.00$ & $\$ 0.00$ & $\$ 0.00$ & $\$ 0.00$ \\
\hline & Place ads in DA & Performed by interns & $\$ 0.00$ & $\$ 0.00$ & $\$ 0.00$ & $\$ 0.00$ \\
\hline & Create event on facebook & Performed by interns & $\$ 0.00$ & $\$ 0.00$ & $\$ 0.00$ & $\$ 0.00$ \\
\hline & & Strategy Subtotal & $\$ 0.00$ & $\$ 0.00$ & $\$ 0.00$ & $\$ 0.00$ \\
\hline & & Public Subtotal & $\$ 5.95$ & $\$ 29.75$ & $\$ 0.00$ & $\$ 29.75$ \\
\hline & & Campaign Total & $\$ 25.88$ & $\$ 487.00$ & $\$ 0.00$ & $\$ 487.00$ \\
\hline
\end{tabular}




\section{Step 9: Communication Confirmation}

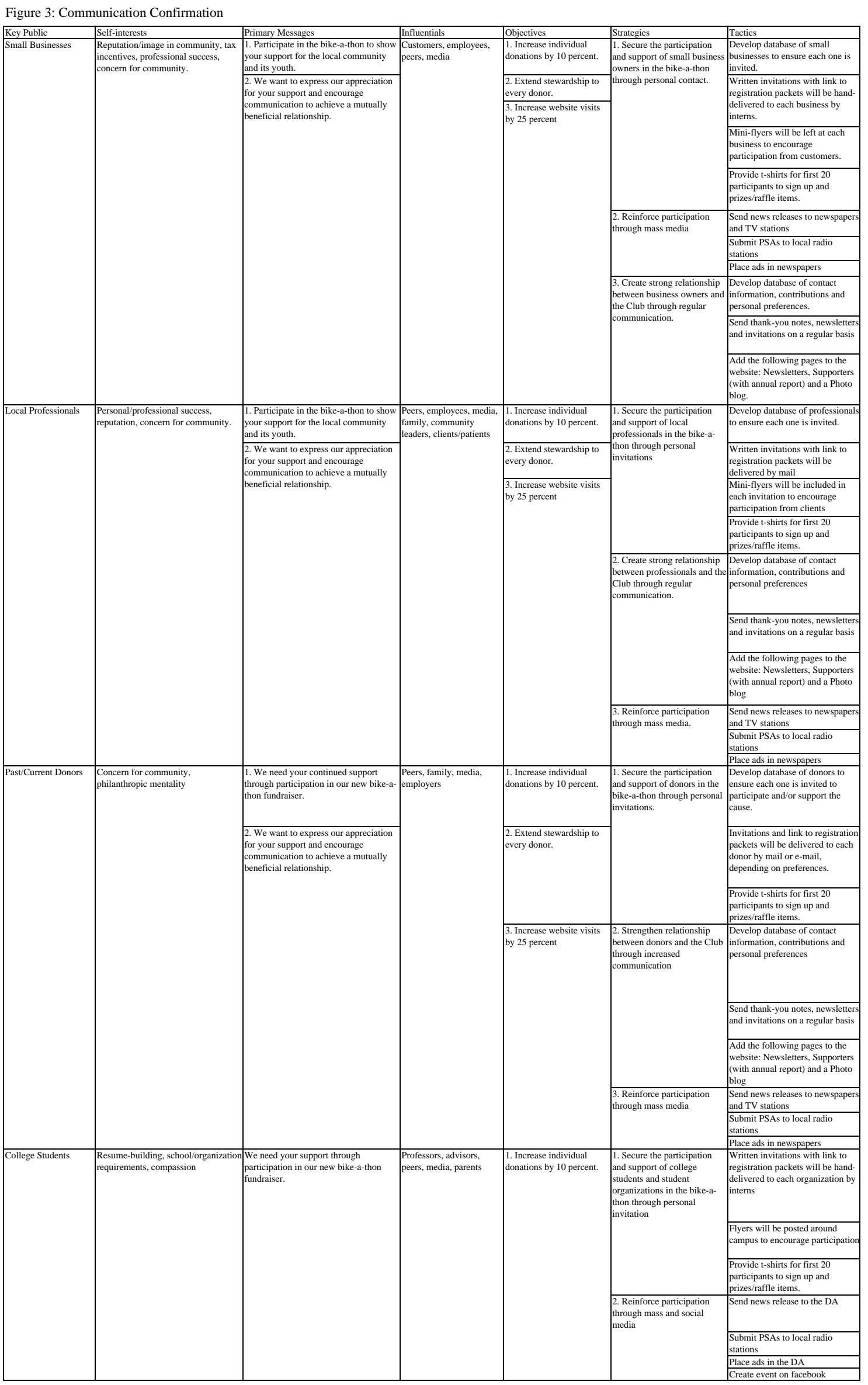




\section{Step 10: Evaluation Criteria and Tools}

Objective 1

Criteria: Individual donations increased by 10 percent.

Tools: Records kept of revenue received from bike-a-thon and other general donations.

Objective 2

Criteria: Stewardship was extended to every donor/supporter.

Tools: Records kept of correspondence between the Club and its supporters.

Objective 3

Criteria: Unique website visits were increased by 25 percent.

Tools: Visitor tracking tools provided by Yahoo!, the Club’s website host. 


\section{References}

2007 County Business Patterns. Provided by West Virginia Development Office.

2008 Mountaineer Boys and Girls Club Annual Report.

Boys and Girls Clubs of America. www.bgca.org.

Botan, C. H., \& Taylor, M. (2004). Public relations: State of the field. Journal of Communication, 54(4), 645-661.

A Brief Community and Economic Profile, 2010 Provided by Morgantown Area Economic Partnership.

Broom, G. M., Casey, S., \& Ritchey, J. (2000). Concept and theory of organizationpublic relationships. In J. A. Ledingham \& S. D. Bruning (Eds.) Public relations as relationship management: A relational approach to the study and practice of public relations (3-22). Mahwah, NJ: Lawrence Erlbaum Associates, Inc.

Cheney, G. \& Christensen, L. T. (2001). Public relations as contested terrain: A critical response. In R. L. Heath (Ed.) Handbook of public relations (167-182). Thousand Oaks, CA: Sage Publications, Inc.

Coombs, W. T. (2001). Interpersonal communication and public relations. In R. L. Heath (Ed.) Handbook of public relations (105-114). Thousand Oaks, CA: Sage Publications, Inc.

David, P. (2004). Extending symmetry: Toward a convergence of professionalism, practice, and pragmatics in public relations. Journal of Public Relations Research, 16(2), 185-211.

Dyer, S., Buell, T., Harrison, M., \& Weber, S. (2002). Managing public relations in nonprofit organizations. Public Relations Quarterly, 47(4), 13. 
Edles, L. P. (1993). Hands-on tactics for nonprofit groups. New York: McGraw-Hill, Inc.

Edwards, R. L., Benefield, E. A. S., Edwards, J. A., \& Yankey, J. A. (1997). Building a strong foundation: Fundraising for nonprofits. Washington, DC: NASW Press.

Freeman, R. E. (1984). Strategic management. Boston: Pitman Publishing Inc.

Golden, K. (2002). The red cross challenged: Success on the web. Retrieved from http://www.techsoup.org/learningcenter/funding/archives/page9615.cfm

Greenfield, J. M. (1991). Fund-raising: Evaluating and managing the fund development process. New York: John Wiley.

Grunig, J. E. (2001). Two-way symmetrical public relations. In R. L.

Heath (Ed.) Handbook of public relations (11-30). Thousand Oaks, CA: Sage Publications, Inc.

Ingenhoff, D. \& Koelling, A. M. (2009). The potential of web sites as a relationship building tool for charitable fundraising NPOs. Public Relations Review 35(1), 6673.

Kang, S., Norton, H. E. (2004). Nonprofit organizations' use of the world wide web: Are they sufficiently fulfilling organizational goals? Public Relations Review 35(3), 279-284.

Kayhko, C. (2009). I think I.T. can, I think I.T. can: E-philanthropy helps small nonprofits reach donors. Nonprofit World 27(5), 10-11.

Kelly, K. S. (2000). The top five myths regarding nonprofits. Public Relations Tactics 7(8), 29-30.

Kelly, K. S. (2001). Stewardship: The fifth step in the public relations process. In R. L. 
Heath (Ed.) Handbook of public relations (279-289). Thousand Oaks, CA: Sage Publications, Inc.

Ledingham, J. A. (2003). Explicating relationship management as a general theory of public relations. Journal of Public Relations Research 15(2), 181-198.

Luckert, K. Nonprofit Organizations (Definition and Examples). http://learningtogive.org/papers/paper41.html

May 2009 Metropolitan and Nonmetropolitan Area Occupational Employment and Wage Estimates. Bureau of Labor Statistics. http://stats.bls.gov/oes/current/oes_34060.htm\#top.

Monongalia County Census Profile. U.S. Census Bureau. http://factfinder.census.gov/home/saff/main.html?_lang=en

Mullen, J. (2006). Using the new media to promote your mission and protect your reputation. Nonprofit World 24(1), 24-27.

Roper, J. (2005). Symmetrical communication: Excellent public relations or a strategy for hegemony? Journal of Public Relations Research 17(1), 69-86.

Sargeant, A. \& Jay, E. (2004). Building donor loyalty: The fundraiser's guide to increasing lifetime value. San Francisco: Jossey-Bass, A Wiley Imprint.

Springston, J. K., Keyton, J., Leichty, G.B., \& Metzger, J. (1992). Field dynamics and public relations theory: Toward the management of multiple publics. Journal of Public Relations Research 4(2), 81-100.

Starck, K. \& Kruckeberg, D. (2001). Public relations and community: A reconstructed theory revisited. In R. L. Heath (Ed.) Handbook of public relations (51-59). Thousand Oaks, CA: Sage Publications, Inc. 
Urban Institute, National Center for Charitable Statistics. http://nccs.urban.org/

Waters, R. D. (2008). Applying relationship management theory to the fundraising process for individual donors. Journal of Communication Management 12(1), 7387.

Wendroff, A. L. (2004). Special events: Proven strategies for nonprofit fundraising. Hoboken, NJ: John Wiley \& Sons, Inc.

West Virginia University. http://www.wvu.edu

Wilson, L. J. \& Ogden, J.D. (2008). Strategic communications planning for effective public relations and marketing (5 ${ }^{\text {th }}$ ed.). Dubuque, IA: Kendall/Hunt Publishing Company.

Worth, M. J. (1993). Educational fund raising: Principles and practice. Phoenix: The Oryx Press. 
Appendix 1: Annual Report 


\section{MOUNTAINEER BOYS AND GIRLS CLUB}

\section{A DECADE OF ACHIEVEMENT}

At the Mountaineer Boys and Girls Club it is a time for celebration. Because we commemorate more than a decade of excellence in 2006, we celebrate what the Mountaineer Boys and Girls Club has meant to our community.

We celebrate our continuity as a united cause and our impact across the community.

We celebrate how the Club has strengthened our community, in good times and bad, changing lives and the community.

We also celebrate the hundreds of caring, productive citizens who claim the Club as their alma mater.

And we celebrate the fact that a decade ago a handful of Morgantown residents united with nothing more - and nothing less - than a dream, a dream to provide hope and opportunity. A dream to inspire and enable all young people to realize their full potential as productive, responsible and caring adults. A dream that started small but grew. A decade old dream that is forever young. Our founders chartered a course that guides us today, through change and challenge, storm and success.

Today we rededicate ourselves to help the young people who need us most. Proud of our past, with faith in our future, we embark on a second decade of service, a decade which begins now.

Irv Schuetzner Chairman
Dennis Poluga

President 


\section{The Mountaineer Boys and Girls Club 2008 Annual Report}

The Mountaineer Boys and Girls Club is a not for profit 501@ (3) organization dedicated to enhancing the quality of life for youth. The Club is a creation of the Chamber of Commerce Vision 2000 Plan which identified the need for an after school program to meet the increase of juvenile crime in the Greenmont area of the community.

In 1998, the Mountaineer Boys and Girls Club was organized after a committee of the Vision 2000 Project, chaired by Otis Cox, investigated the various ways to meet our community's needs. The committee felt an after school program based on the Boys and Girls Club model would be the most effective method of dealing with the community's juvenile delinquency problem.

\section{MISSION}

The primary mission of the Mountaineer Boys and Girls Club is to promote health, social education, education enhancement opportunities, and character development for boys and girls grades 1 through 12, by building self-esteem, values, and social skills. The Boys and Girls Club provides programs that are tested, proven, and nationally recognized as successfully addressing the most critical issues affecting today's youth. The Club also provides them with the knowledge, skills, and attributes they need to pursue their dreams and succeed in life.

\section{FACILITY}

The Boys and Girls Club is located in the City of Morgantown’s Central Business District in a building that formerly housed the Dominion Post Newspaper. The facility is in excess of 70 years old and requires constant attention. However, the facility is located in an area that is readily available to the Club's members. Many students are able to catch a school bus to within one block of the Club and both City High Schools are within a three block walking distance to the Club. Also note, the Club's downtown location places it within easy walking distance for the large number of WVU students who volunteer at the Club.

\section{WHO WE SERVE}

Currently, the Mountaineer Boys and Girls Club serves an excess of 700 members. The Club serves 60 to 70 members per day during the academic year. During the summer months, the number of members served per day increases to 80 to 90 members. The Club serves a gender mix of equal proportions. Approximately 9\% of members are African Americans, 21\% are mixed race, and 5\% are Hispanic or Asian. Caucasians make up approximately $65 \%$ of the Club’s membership.

Many of the members live in households with limited means. Most parents are employed in entry-level positions in the retail segment of the economy and at times they are required to 
work irregular hours. Hence, they become dependent on the Club to provide their children with education support services in a safe after-school setting. The Boys and Girls Club requires a low membership due between $\$ 10.00$ per month to $\$ 35.00$ per month. Members who are unable to afford the dues are able to volunteer services to the Club for fundraisers to offset the due. Examples are working at concession stands, bucket brigades, and collecting donations at WVU games. They can also help with maintenance problems at the Club. Members are also offered a scholarship or reduced cost application. Qualifying families will receive free or reduced membership. Eligible families include families that are in college and can't work or families that work a minimum wage job with more than one member.

\section{PROGRAMS}

EDUCATION: Project Learn is a program that helps develop Club members' knowledge and skills by integrating fun and educational activities. This program consists of five components: homework help and tutoring, high-yield learning activities, parental involvement, collaboration with the schools, and recognition and incentives to Club members. These strategies work together to support Club members in reaching their full potential. The program does this by helping them become proficient in basic academic skills, teaching them to make informed decisions about post secondary education, and encourage them to become lifetime learners. Project Learn operates Monday through Thursday from 3-4pm, and from 5-7pm, and on Fridays from 3-7pm. The Project Learn Room is a designated, quiet place for children who have extra homework, need extra study time, want to research scholarships, or need any one on one tutoring. Staff, community members, as well as WVU students (provided through the WVU Office of Service Learning, and WVU Departments of: Education, Psychology, Criminology, Communications, Social Work, and Public Relations) assist students with homework, facilitate study groups, tutor, and teach a wide variety of high yield learning activities. Example of these include reading newspapers, worksheets, computer skills, building birdhouses, books on tape, talent shows, and stock classes, etc.

Power Hour is a comprehensive homework help and tutoring program that operates Monday through Thursday from 4-5pm in a designated, quiet area. Power Hour is a mandatory education time designed to encourage academic success. Power Hour provides members with support, resources and guidance necessary to complete their homework and start the school day with a sense of confidence and ability. As members complete homework assignments and bonus activities, they accumulate Power Points, which may be used to obtain Power Rewards - prizes, activities, and incentives. In addition, Power Hour offers tutoring assistance for members who need additional work in special areas. Beyond the academic benefit, consistent homework completion helps young people develop valuable organizational skills including time management, prioritizing and task completion. Power Hour enables the Club to provide extra attention and focused assistance to at-risk members and those in need of motivation and direction. With proper guidance and support, every Club member has the chance to develop selfdirected learning skills and to be successful in school.

CAREER LAUNCH: The Mountaineer Boys and Girls Club continues to promote career development programs as a key component of its youth development strategy. Included in the 
strategy are the Career Explorers Program, the Money Matters Program, and a Learning Strategies Program.

The Career Explorers Program enables Club members ages 14-18 to gain insights and practical skills in finding, obtaining and keeping a job, as well as laying the groundwork for their career futures. Fundamental skills are developed through 22 short activities that are easy to understand and conduct. The Launch web site supports the Career Explorers curriculum. This web site allows teens to assess their interests and match them with more than 300 career options.

People become the best money managers when they have the chance to develop these skills early in life. When young people learn the skills that lead to financial independence, they are better prepared to reach their potential as productive, responsible, and caring citizens. The Money Matters Program enables the Club to empower their members with practical ways to save, spend, and invest the money they will earn. Through the Money Matters Program, Club teens will learn to make sound financial plans and develop financial goal for the future. Money Matters sessions are designed to be engaging, hands on, and geared to teen's ages 13-18. The Money Matters Program was developed in concert with the Charles Schwab Foundation. The Money Matters Program is funded in part by JP Morgan Chase, the Verizon Foundation, and the Mollohan Foundation.

The Learning Strategies Program is offered two days each week during the summer to members 13-16. The Program teaches a variety of strategies in order to develop strong learning and studying skills.

MENTORING: Recognizing these needs, our Club offers two mentoring program through the Mountaineer Boys and Girls Club. The Monongalia Mentoring Program is a traditional mentoring program offered at the Boys and Girls Club, the Shack Neighborhood House and four school-based after-school sites. In this program, screened and trained mentors spend one hour a week of an entire year with their mentee. The goal is to create healthy one on one relationships. (Due to the increase of single parent homes, today's youth have fewer opportunities to have supportive relationships with adults. These relationships are important because young people seek out parents and other adults as a source of advice and overall support).

Since March of 2003, the Program has worked with an average of 30 students a month with a total of 211 different students served, and has been supported since its inception by 40 volunteers who have provided support in mentoring, tutoring and volunteer recruitment.

PREVENTION: SMART MOVES is a research-based program of current and effective prevention techniques that helps young people deal with three of the most immediate threats to their well-being: alcohol, other drugs and teen pregnancy. In small age appropriate groups, participants engage in discussion and role-playing aimed at:

- Enhancing skills to identify and resist peer, social and media pressures;

- Improving "life skills” to make decisions, cope with stress, and communicate effectively,

- Transmitting essential and accurate information about alcohol, other drugs, and adolescent sexuality, 
- Increasing communication between youth, parents, and guardians regarding alcohol, other drugs, and adolescent sexuality, and

- Promoting community awareness and establishing a Club environment that encourages young people to say NO and to make healthy choices.

The focus of this effort is "no" drug use as opposed to "responsible" drug use; and the postponement of sexual involvement as opposed to contraceptive education. SMART MOVES is based on a health promotion model that recognizes any changes in the normal body chemistry as harmful or of potential harm to the developing young person. SMART Kids is a prevention program for youth ages 6-9. It helps members to identify ways to say "no" to drugs and alcohol, proper and improper ways of touching, and general facts about drugs, alcohol, and tobacco. Start Smart is a resistance skills training program for youth ages 10-12. It helps members to identify ways to resist peer, social, and media pressure to use alcohol, other drugs, and to become involved sexually. It incorporates resistance skills, stress reduction techniques, communication skills, assertive training, life planning, and accurate information about drug use and adolescent sexuality. SMART Girls is a program designed for girls ages 13-17. Its main goals are to develop and enhance the skill necessary for a healthy lifestyle; develop an appreciation of their bodies and the physical, emotional, and social changes they are experiencing; develop lifelong nutritional habits; and develop communication skills through the involvement of adult female role models to enhance important female relationships. Stay SMART is a prevention program designed for students ages 13-17 (we focus on boys 13-17). Stay SMART focuses on decision making, media, self-image, coping with adolescence (puberty and stress), relationships, social skills with dating, and life planning.

FITNESS HOUR: Through weekly classes and varied activities, such as games, ice skating, bowling, dance, and various sports, members of the Boys \& Girls Club will improve the quality and quantity of physical activity achieved on a weekly basis. The objective of these classes is not only to improve their value of fitness and activity, but also to teach them fun ways to take health into their own hands and inspire them to stay active outside of structured activities. In a working relationship with the schools, information is provided on the diverse sports offered by each school and their athletic programs, as well as those intramural sports available to the club members throughout Morgantown and its surrounding areas.

On a daily basis, the Club ensures that the members are staying active by encouraging outside sports and activities such as basketball, soccer, and even tag. When weather does not permit outside play, exercise is promoted through activities such as Dance Dance Revolution competitions, Zumba, and yoga.

NUTRITION: Through grants sponsored by the United Way of Monongalia and Preston Counties, and working through the Healthy Together Network, a VeggieU program will be started this year for children in $4^{\text {th }}$ and $5^{\text {th }}$ grade. This program will teach these students how to plant, maintain, and cultivate vegetables. Through various activities including a worm farm, plant experiments, and composting, the students will learn hands-on how to grow their own vegetables and gain a better understanding on the importance of nutrition, plant life, and balancing one's lifestyle with nutrition. 
VeggieU will be extended to all club members in teaching them about diet and nutrition, plant care, anatomy of worms, parts of a plant, processes of composting, as well as the differences between conventional and naturally grown vegetables. Classes will be given on a weekly basis to maintain constancy within the group.

In an effort to fight the increasing obesity rates in West Virginia, a holistic view has been shown to be the most effective way of battling this problem. Teaching kids about healthy ways to deal with stress, low self-esteem, and bullying are all important aspects of the child's overall health.

CHARACTER EDUCATION: Character Education is a structured program focusing on building member character and self-esteem by identifying and practicing specific virtues. The program is a tool the staff uses to guide and teach members the content of their character is a first priority.

The Virtues Initiative is an important part of all Mountaineer Boys and Girls Club programs and activities. The Virtues Initiative is a process by which all Club members and staff agrees to adhere to a specific code of conduct and moral compass. The Virtues Initiative is based on four key principals.

- The parent is the primary educator of the child.

- Children are born of potential: their natural qualities can develop into positive or negative traits depending on how they are educated in their early years.

- Character develops as children learn to make responsible, moral choices.

- Self-esteem is a natural outcome of living by spiritual principles.

There are five strategies used in the Virtues Initiative process.

- Speak the language of virtues

- Recognize teachable moments

- Set clear boundaries

- Honor the spirit

- Offer the art of spiritual companioning

It is important to note spiritual and religious are not synonyms, Boys and Girls Clubs do not promote one religion. Boys and Girls Clubs promote, encourage, and nurture the development of values and a moral compass to allow children to make responsible and healthy choices. The use of Virtues facilitates this process in all Mountaineer Boys and Girls Club programs and activities including Project Learn. The Virtues Initiative allows our members and families to develop character and leadership at the Club, at home, at school, and in their community.

COMMUNITY SERVICE: Youth United is a program developed by the United Way. The program serves as a vehicle for Club members to participate in community service activities. The Club has adopted a portion of the Decker's Creek Rail-to-Trail and the Dog Park as its community service project. Club members can participate in many community service projects throughout the calendar year. All Club members are required to provide 30 hours of community service each year. 
FAMILY PLUS: The Family PLUS program is designed to form collaborations with parents and caregivers as partners in the positive development of children. By working with parents and caregivers in the safe environment of the Club, it is possible for Club staff to help families spend more valuable time together and promote a more integrated network of support for both families and Club members. When this is accomplished, the Club assists in ensuring that families have the opportunities, networks, and assistance needed to realize their aspirations for their children. There are three components that complete the program: Kinship Care, Father Involvement and Family Advocacy Network.

Kinship Care consists of providing knowledge and resources to extended family members who have assumed the parenting role as primary caregivers. The Club will develop collaborations with the community agencies that serve as resources for caregivers. The Club will also provide on-site programming opportunities such as tutoring, recreational activities, support groups, and relative workshops.

Paternal Involvement has been shown to promote positive youth outcomes. The Club supports Father Involvement through activities, training, and services to help increase involvement in the lives of their children. Fathers will volunteer at the club and spend quality time with their child at various Club arranged activities.

The Family Advocacy Network is a model of group support for parents and caregivers of Boys and Girls Club members who are participating in one of the Club's prevention programs. Through the Family Advocacy Network, parents and caregivers receive empowerment through leadership, educational and social activities, and individual support. This network empowers families with the knowledge necessary to advocate for their children.

\section{MEMBERS}

The Mountaineer Boys and Girls Club members, although generally economically disadvantaged, have shown progress in a variety of areas.

- Sixty-one percent of the Club members who attend Club at least two days a week during the school year have a "B" grade point average or higher.

- None of our Club members were referred to the Probation Office for truancy issues.

- Club members adopted a portion of Decker's Creek Rail-to-Trail and provided over 5,000 hours of community service there.

- Club members participate at least monthly in the United Way's Youth United Program.

- $90 \%$ of the club members complete the Club's Character Education and Prevention Programs. 


\section{PROGRAM YEAR GOALS}

The present focus of the Mountaineer Boys and Girls Club is academic support, prevention services, and character education. Specific Club goals for the year include:

- Increasing achievement in math and reading for Club members.

- Utilizing standardized, school based tests to evaluate student academic levels of performance.

- Helping children develop greater confidence in their academic abilities. Pre and post-test members to assess their confidence.

- Increasing confidence to 50\% of Club members who are regular Power Hour participants.

- Increasing school attendance rates.

- Maintaining 95\% of Club members having fewer than 5 unexcused absences per year.

- Improving student behavior in the classroom through Character Education techniques.

- Reducing $40 \%$ of behavior incidences reported on school report cards.

- Providing academic support during the summer months through one hour a day of support services.

- Offering basic skills classes to $100 \%$ of Club members during the summer program.

- Offering SMART Moves curriculum to $100 \%$ of Club members.

- Pre and Post-testing members in order to achieve a 10\% increase in knowledge about prevention issues.

\section{SUPPORTERS}

A special thanks to the many who support the Mountaineer Boys and Girls Club:

- JP Morgan Chase

- $\quad$ The United Way

- The Boys and Girls Clubs of America

- US Department of Justice

- US Department of Education

- Mylan Pharmaceuticals

- Mollohan Foundation

- Nailer Foundation

- Verizon Foundation

- HOTT Brown Foundation

- Monongalia County Commission

- City of Morgantown

- J.C. Penny's

- Staples 
- Finish Line

- Cheat Lake Rotary

- Wal-Mart- Granville, WV

- Target

- Cold Stone

- Black Bear

- Hazel Ruby McQuain Charitable Trust

- Appalachian Gallery

- Bon Ton

- Beta PSI Chapter

- Board of Education

- Alpha Delta Kappa

- Sheetz

- Community Newcomers Club

- Jacksonville Chapel

- Rotary Club of Morgantown

- GAP Foundation

- Barnes and Noble 


\section{Appendix 2: Interview Questions}

What role does the Club serve in the local community?

What problems does the Club face?

What does the Club do well?

Are there any opportunities that you would like to take advantage of that would help the success of the Club?

What events or trends in the community could potentially threaten the success of the Club?

What are your goals for 2010 ?

Any ideas on how to achieve these goals?

Who are the major stakeholders of the Club?

How has the Club been successful with public relations and/or fundraising in the past?

What, if any, public relations and/or fundraising efforts are already being planned for 2010?

Where does funding for the Club come from? How much comes from each source?

What are you operating costs? What specifically are your funds used for?

Is there anything specific that you need more funding for?

Describe any relationships with outside groups.

How many staff members are there? Volunteers?

If funding was available, would you want to move the Club to a bigger facility? Or would you rather expand/improve the facility you already have?

Do you send the annual report out to the donors?

Do you have any plans for revamping the website?

Additional comments: 
Appendix 3: Planning Matrix

$\underline{\text { Research }}$

Step 1: Background:

-Description and mission statement

-Organizational Goals \& Objectives

-External Environment (Demographic, Social-Cultural, Economic, Legal-

Political and Technological current or future trends)

-Past successes/failures of PR efforts and/or fundraisers

-Competition (Strengths \& Weaknesses)

-Resources (Potential publics, current relationships, public attitudes)

-SWOT Analysis

Step 2: Situation Analysis

Step 3: Core Problem/Opportunity

Action Planning

Step 4: Goals and Objectives

Step 5: Key Publics and Messages

Step 6: Strategies and Tactics

Step 7: Calendar

Step 8: Budget

$\underline{\text { Communication }}$

Step 9: Communication Confirmation

$\underline{\text { Evaluation }}$

Step 10: Evaluation Criteria and Tools 
Appendix 4: SWOT Analysis

\begin{tabular}{|l|l|}
\hline \multicolumn{1}{|c|}{ Strengths } & \multicolumn{1}{c|}{ Weaknesses } \\
$\begin{array}{l}\text { Academic support services } \\
\text { Character education programs } \\
\begin{array}{l}\text { Prevention programs } \\
\text { Community service opportunities }\end{array}\end{array}$ & $\begin{array}{l}\text { Lack of space } \\
\text { Forced to turn kids away } \\
\text { Lack of funding for utilities, rent, } \\
\text { maintenance and transportation }\end{array}$ \\
\hline $\begin{array}{l}\text { Opessage of success into the community } \\
\text { More kids in community wish to be } \\
\text { members } \\
\text { WVU and Greek organizations }\end{array}$ & $\begin{array}{l}\text { Threats } \\
\text { Funding agencies only willing to fund } \\
\text { specific programs }\end{array}$ \\
\hline
\end{tabular}


Appendix 5: Sample News Release 


\section{Mountaineer Boys \& Girls Club 300 Court Street \\ Morgantown, WV 26505 \\ (304)292-7510}

\section{Mountaineer Boys \& Girls Club to hold Bike-a-Thon}

Morgantown, W.Va., Tuesday March 1, 2011---The Mountaineer Boys \& Girls Club will be holding their $1^{\text {st }}$ annual poker run on Saturday, April $9^{\text {th }}$.

Registration forms are available at Wamsley Cycles and the Boys \& Girls Club. Forms may also be downloaded off the website, mbcg.org. Make sure to register by March $15^{\text {th }}$ in order to receive the Early Registration discount. The first 20 people to register will receive a t-shirt.

"We are very excited about this fundraiser," said Kira Gandolfi, Program Manager for the Mountaineer Boys \& Girls Club. "We have a lot of great prizes in store for all the bikers."

Registration begins at 11 a.m. on April $9^{\text {th }}$ at Wamsley Cycles. The last bike will be out at noon. Prizes will be given to the oldest biker, youngest biker, best time and most money raised.

"I encourage everyone to make this a family event," said Denny Poluga, Director of the Mountaineer Boys \& Girls Club. "The staff is eager to get the event underway and we are inviting the community to join in on the excitement."

For more information contact the Boys \& Girls Club at (304)292-7510 or email Kira Gandolfi at kira.gandolfi@yahoo.com.

-END- 